\title{
Interaction between paraventricular nucleus and septal area in the control of physiological responses induced by angiotensin II
}

L.A.A. Camargo ${ }^{1}$, W.A. Saad ${ }^{1,2}$, S. Simões ${ }^{2}$ T.A.B. Santos ${ }^{2}$ and W. Abrão Saad ${ }^{3}$

\author{
1Departamento de Fisiologia, Faculdade de O dontologia, \\ Universidade Estadual Paulista, Araraquara, SP, Brasil \\ ${ }^{2}$ Departamento de O dontologia, Universidade de Taubaté, \\ Taubaté, SP, Brasil \\ ${ }^{3}$ Departamento de Cirurgia, Faculdade de Medicina, \\ Universidade de São Paulo, São Paulo, SP, Brasil
}

\section{Correspondence \\ L.A.A. Camargo \\ Departamento de Fisiologia \\ Faculdade de O dontologia, UNESP \\ Rua Humaitá, 1680 \\ 14801-903 Araraquara, SP \\ Brasil \\ Fax: +55-16-201-6488 \\ E-mail: silvana@foar.unesp.br}

Presented at the IV International Symposium on Vasoactive Peptides, Belo Horizonte, M G, Brazil,

October 19-21, 2001.

Research supported by CNPq (No. 520408/96-9) and FAPESP (No. 99/06582-2).

Received August 13, 2001 Accepted September 20, 2001

\section{Abstract}

We determined the effects of losartan (40 nmol) and PD 123319 (40 nmol) (both non-peptides and selective antagonists of the $\mathrm{AT}_{1}$ and $\mathrm{AT}_{2}$ angiotensin receptors, respectively), and $\left[\mathrm{Sar}^{1}, \mathrm{Ala}^{8}\right]$ angiotensin II (ANG II) (40 nmol) (a non-selective peptide antagonist of angiotensin receptors) injected into the paraventricular nucleus (PVN) on the water and salt appetite, diuresis and natriuresis and mean arterial pressure (MAP) induced by administration of $10 \mathrm{nmol}$ of ANG II into the medial septal area (MSA) of male Holtzman rats weighing 250$300 \mathrm{~g}$. The volume of drug solution injected was $0.5 \mu \mathrm{l}$ over a period of 10-15 s. The responses were measured over a period of $120 \mathrm{~min}$. ANG II alone injected into the MSA induced an increase in all the above parameters $(8.1 \pm 1.2,1.8 \pm 0.3$, and $17.1 \pm 1.0 \mathrm{ml}, 217 \pm 25$ $\mu \mathrm{Eq} / 120 \mathrm{~min}$, and $24 \pm 4 \mathrm{mmHg}$, respectively, $\mathrm{N}=10-12)$ compared with vehicle-treated rats $(1.4 \pm 0.2,0.6 \pm 0.1$, and $9.3 \pm 0.5 \mathrm{ml}, 47 \pm 5$ $\mu \mathrm{Eq} / 120 \mathrm{~min}$, and $4.1 \pm 0.8 \mathrm{mmHg}$, respectively, $\mathrm{N}=10-14)$. Pretreatment with losartan and $\left[\mathrm{Sar}^{1}, \mathrm{Ala}^{8}\right]$ ANG II completely abolished the water and sodium intake, and the pressor increase $(0.5 \pm 0.2,1.1 \pm 0.2$, $0.5 \pm 0.2$, and $0.8 \pm 0.2 \mathrm{ml}$, and $1.2 \pm 3.9,31 \pm 4.6 \mathrm{mmHg}$, respectively, $\mathrm{N}=9-12$ ), whereas losartan blunted the urinary and sodium excretion induced by ANG II $(13.9 \pm 1.0 \mathrm{ml}$ and $187 \pm 10 \mu \mathrm{Eq} / 120 \mathrm{~min}$, respectively, $\mathrm{N}=9$ ). Pretreatment with $\mathrm{PD} 123319$ and [Sar ${ }^{1}, \mathrm{Ala}^{8}$ ] ANG II blocked the urinary and sodium excretion $(10.7 \pm 0.8,9.8 \pm 0.7$ $\mathrm{ml}$, and $67 \pm 13$ and $57 \pm 17 \mu \mathrm{Eq} / 120 \mathrm{~min}$, respectively, $\mathrm{N}=9$ ), whereas pretreatment with PD 123319 partially blocked the water and sodium intake, and the MAP induced by ANG II administration $(2.3 \pm$ $0.3,1.1 \pm 0.1 \mathrm{ml}$, and $12 \pm 3 \mathrm{mmHg}$, respectively, $\mathrm{N}=9-10)$. These results suggest the angiotensinergic effect of the MSA on the $\mathrm{AT}_{1}$ and $\mathrm{AT}_{2}$ receptors of the $\mathrm{PVN}$ in terms of water and sodium homeostasis and MAP modulation.
Key words

- $\mathrm{AT}_{1}$ receptors

- $A T_{2}$ receptors

- Water

- Sodium

- Paraventricular nucleus

- Medial septal area 


\section{Introduction}

Considerable evidence supports the view that brain angiotensin II (ANG II) plays an important role in the regulation of pressor responses, thirst, sodium appetite, and release of vasopressin (1). The paraventricular nucleus of the hypothalamus (PVN) is known to be an important center for the integration of the neural signals involved in arterial pressure, drinking, and vasopressin release (2). The septal area and the PVN are areas of the brain closely involved in fluid, electrolytic and cardiovascular regulation $(3,4)$.

Recently, two angiotensin receptor subtypes, $\mathrm{AT}_{1}$ and $\mathrm{AT}_{2}$, have been identified on the basis of selective antagonists. Although most brain nuclei expressing ANG II receptors contain only one subtype, some nuclei express a mixture of $\mathrm{AT}_{1}$ and $\mathrm{AT}_{2}$ receptors (5).

The PVN is known to contain predominantly $\mathrm{AT}_{1}$ subtype receptors (6), but it has been shown that the excitatory action of angiotensin on paraventricular neurons is antagonized by the ANG II receptor $\mathrm{AT}_{2}$ (7). Both $\mathrm{AT}_{1}$ and $\mathrm{AT}_{2}$ sites are also present in the septum (8).

Since the septum has known anatomic connections with the PVN (9) we determined the effect of previous PVN treatment with losartan, PD 123319 (non-peptide angiotensin receptor antagonists) and [Sar ${ }^{1}$, $\left.\mathrm{Ala}^{8}\right]$ ANG II (non-selective angiotensin receptor antagonist) on water and salt intake, urine and sodium excretion and blood pressure responses induced by administration of ANG II into the medial septal area (MSA).

\section{Material and Methods}

\section{Animals}

Male albino Holtzman rats weighing 250$300 \mathrm{~g}$ were used in all experiments. The rats were housed individually in a temperaturecontrolled room $\left(23 \pm 2^{\circ} \mathrm{C}\right)$ on a 12:12-h light-dark cycle. Food pellets $\left(\mathrm{Na}^{+}\right.$content $5 \mathrm{mEq} / 100 \mathrm{~g}$ ) and water were available $\mathrm{ad}$ libitum unless stated otherwise. All experiments began at 9:00 $\mathrm{h}$.

\section{Brain surgery}

Animals were anesthetized with tribromoethanol $(20 \mathrm{mg} / 100 \mathrm{~g}$ body weight, ip $)$. Stainless steel guide cannulae $(0.6 \mathrm{~mm}$ outer diameter, $0.33 \mathrm{~mm}$ inner diameter) were implanted into the MSA using the following coordinates: $1.20-1.00 \mathrm{~mm}$ anterior to the bregma in the midline, and to a depth of 4.2 $\mathrm{mm}$ from the duramater. For cannula implantation into the PVN (unilaterally) the following coordinates were used: $0.2-0.6 \mathrm{~mm}$ lateral to the sagittal line, $6.0 \mathrm{~mm}$ down the duramater and $1.8-2.0 \mathrm{~mm}$ posterior to the bregma (10). The cannula was secured to the top of the skull with dental cement and fastened with two screws. The insertion of a close fitting stylet kept the lumen free of debris and clots. A prophylactic dose of penicillin $(30,000 \mathrm{IU})$ was administered three days before and three days after surgery.

\section{Intracerebral injection techniques}

After brain surgery, the animals were returned to individual metabolic cages, with free access to granular ration and tap water for one week until the day of the experiment. A dental needle ( $0.3 \mathrm{~mm}$ outer diameter) 2.0 $\mathrm{mm}$ longer than the cannula fixed to the skull was used for the injections. The needle was connected by PE tubing to a Hamilton-type syringe $(5 \mu 1)$ kept outside the cage. All drugs were injected in $0.5-\mu l$ volumes over $10-15 \mathrm{~s}$.

\section{Drugs}

ANG II and $\left[\mathrm{Sar}^{1}, \mathrm{Ala}^{8}\right]$ ANG II were purchased from Sigma (St. Louis, MO, USA), and losartan and PD 123319 were from DuPont-Merck (Wilmington, DE, USA). 
Sodium concentration in urine samples was measured with a NOVA $1+1$ apparatus.

\section{Brain histology}

At the end of the experiments, the rats were anesthetized with ether and perfused through the heart with $10 \%$ saline and $10 \%$ formalin solution. The brains were removed, fixed in $10 \%$ formalin for one week, frozen, cut into $20-30-\mu \mathrm{m}$ sections and stained with hematoxylin. Only animals in which the injection was placed in the MSA were used in this study (Figure 1). The PVN parameters studied were observed in subjects that had the injection placed in the lateral parvocellular and medial posterior magnocellular subdivisions of the PVN (10) but not in subjects in which the injections were placed in the fornix, zona incerta, reuniens thalamic nucleus, dorsal and medial parvocellular nuclei, or periventricular subdivisions of the PVN (Figure 2).

\section{Statistical analysis}

Data are reported as means \pm SEM. The results were analyzed statistically by oneway analysis of variance (ANOVA), followed by comparisons between individual means using the Newman-Keuls post hoc test. Differences at the $5 \%$ level $(\mathrm{P}<0.05)$ were considered to be significant.

\section{Experimental design}

Water and sodium intake. To determine the accuracy of MSA or PVN placement, the animal was offered drinking water immediately after ANG II (10 pmol) injection. Water ingestion $(4 \mathrm{ml})$ within $15 \mathrm{~min}$ of the injection was presumptive evidence of correct positioning of the cannula in the MSA or PVN. This test was performed at least $72 \mathrm{~h}$ prior to the water and sodium intake experiments.

Seven days after brain surgery, water and
$3 \% \mathrm{NaCl}$ intake were measured in different groups after injection of saline $(0.15 \mathrm{M} \mathrm{NaCl})$ and ANG II $(10 \mathrm{pmol})$ into the MSA. The effect of pretreatment with the ANG II receptor antagonists on ANG II-induced water or $3 \% \mathrm{NaCl}$ intake was tested with [Sar ${ }^{1}$, Ala $^{8}$ ] ANG II (40 nmol), losartan (40 nmol) and PD 123319 (40 nmol) injected into the PVN 15 min before ANG II injection into the MSA. Water and 3\% $\mathrm{NaCl}$ intake were recorded at 30-min intervals for $2 \mathrm{~h}$ after the injection of the antagonists.

Urine and sodium excretion. Five days after brain surgery, catheters (PE-50 polyethylene tubing) were inserted under 2,2,2tribromoethanol anesthesia $(20 \mathrm{mg} / 100 \mathrm{~g}$ body weight) into the superior vena cava via the right external jugular vein and externalized between the scapulae. Two days after surgery, animals were submitted to the experimental session. After $12 \mathrm{~h}$ of water and $3 \% \mathrm{NaCl}$ solution deprivation, the catheters were connected to $10-\mathrm{ml}$ syringes driven by a Harvard Apparatus infusion pump. Intra-

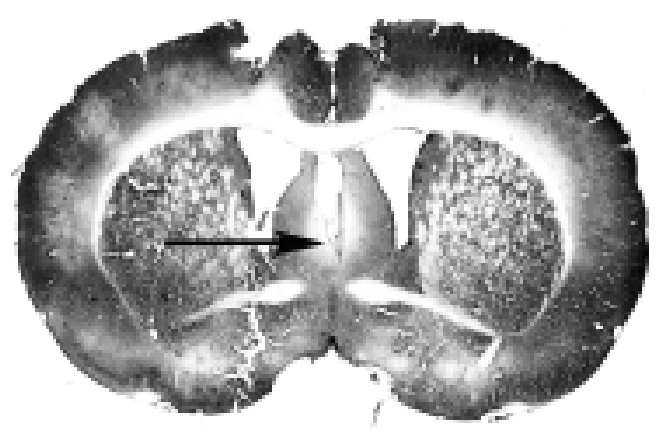

Figure 1. Photomicrograph of a hematoxylin-stained transverse section of the rat brain showing the site of injection into the medial septal area (arrow). Magnification 8X.

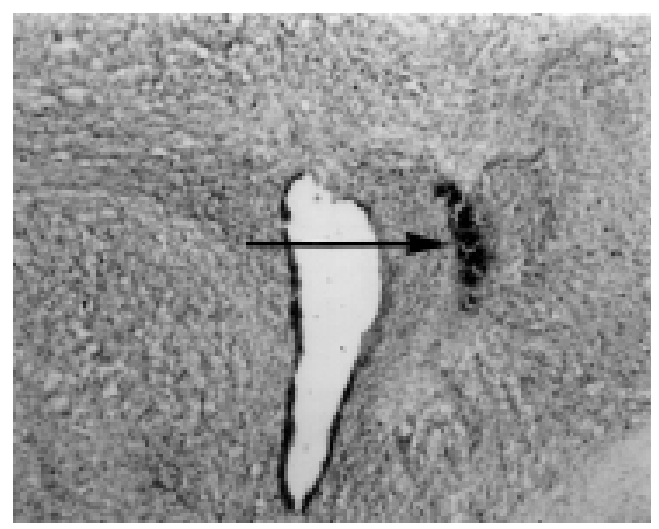

Figure 2. Photomicrograph of a hematoxylin-stained transverse section showing the site of injection into the paraventricular nucleus (arrow). Magnification 40X. 
venous infusion of hypotonic saline $(0.08 \mathrm{M}$ at $1.5 \mathrm{ml} / \mathrm{h}$ ) was started to promote urinary flow, and $3 \mathrm{~h}$ were allowed for equilibration. Urine excretion was recorded at 30-min intervals for $2 \mathrm{~h}$ after injection of the ANG II antagonists. Different groups received isotonic saline vehicle and ANG II (10 nmol) into the MSA, and the ANG II antagonists (40 nmol) into the PVN 15 min before ANG II.

\section{Mean arterial pressure}

Mean arterial pressure (MAP) was recorded in unanesthetized and unrestrained rats through polyethylene tubing (PE-10 connected to a PE-50) inserted into the abdominal aorta through the femoral artery under 2,2,2-tribromoethanol anesthesia $(20 \mathrm{mg} / 100$ $\mathrm{g}$ body weight) on the day before the recording. The polyethylene tube was tunneled subcutaneously to the back of the rat and was connected to a Statham $(\mathrm{P} 23 \mathrm{Db})$ pressure transducer (Statham-Gould) coupled to a

Figure 3. Effect of pretreatment with [Sar ${ }^{1}$, Ala $\left.^{8}\right]$ ANG II (SAR, 40 $\mathrm{nmol}$ ), losartan (LOS, $40 \mathrm{nmol}$ ), and PD 123319 (PD, $40 \mathrm{nmol}$ ) into the paraventricular nucleus on water intake induced by injection of ANG II (10 nmol) into the medial septal area. Data are reported as means \pm SEM. The number of animals is indicated at the top of each column. ${ }^{*} \mathrm{P}<0.05$ compared with saline (control); $+\mathrm{P}<0.05$ compared with ANG II; \#P<0.05 compared with losartan (ANOVA).

Figure 4. Effect of pretreatment with [Sar ${ }^{1}$, Ala $\left.{ }^{8}\right]$ ANG II (SAR, 40 $\mathrm{nmol}$ ), losartan (LOS, $40 \mathrm{nmol}$ ), and PD 123319 (PD, $40 \mathrm{nmol}$ ) into the paraventricular nucleus on sodium intake induced by injection of ANG II (10 nmol) into the medial septal area. Data are reported as means \pm SEM. The number of animals is indicated at the top of each column. ${ }^{*} \mathrm{P}<0.05$ compared with saline (control); ${ }^{+} \mathrm{P}<0.05$ compared with ANG II; \#P<0.05 compared with losartan (ANOVA).
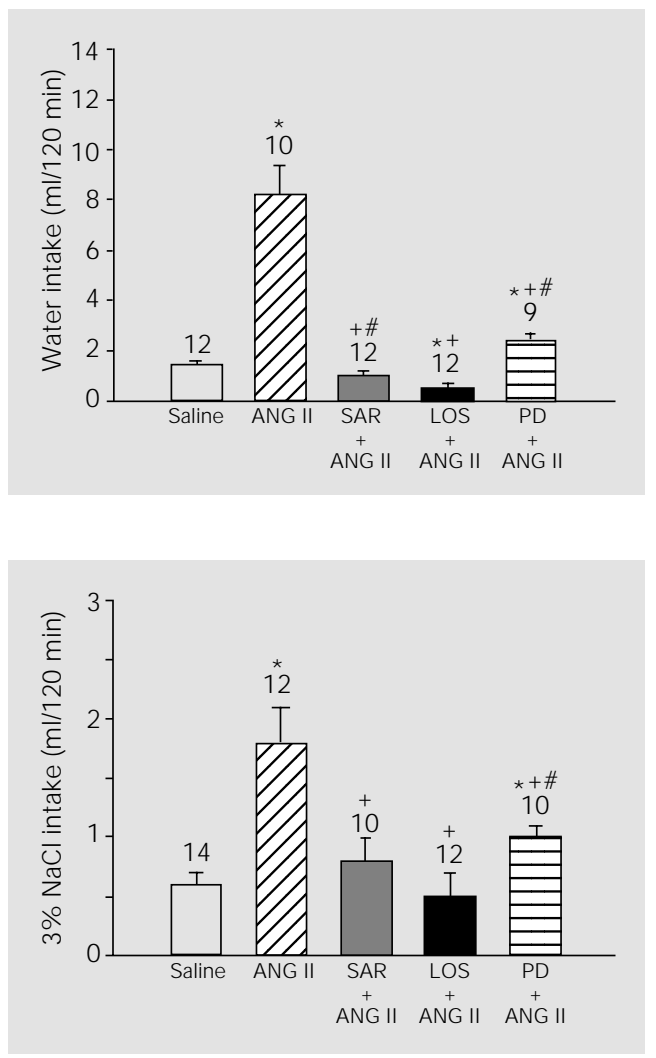

multichannel recorder (Physiograph, Narco Bio-Systems, Houston, TX, USA). The drugs were injected using the same doses as described above.

\section{Results}

Effects of [Sar ${ }^{1}$, Ala $\left.^{8}\right]$ ANG II, losartan, or PD 123319 injected into the PVN on water and saline ingestion induced by ANG II injected into the MSA

The water ingestion observed for $2 \mathrm{~h}$ in the control experiment $(0.15 \mathrm{M} \mathrm{NaCl})$ and with the injection of the angiotensin antagonists is presented in Figure 3. Analysis of variance for the 2-h cumulative water intake showed that the different treatments significantly affected water intake $(\mathrm{F}(4.50)=33.06$, $\mathrm{P}<0.05)$. ANG II administration significantly increased water intake when compared with saline controls. Cumulative water intake induced by ANG II was totally inhibited in animals previously treated with $\left[\mathrm{Sar}^{1}, \mathrm{Ala}^{8}\right]$ ANG II and losartan, and partially inhibited by previous treatment with PD 123319.

Analysis of variance was performed for the cumulative 2 - $\mathrm{h}$ saline intake $(\mathrm{F}(4.51)=$ $11.67, \mathrm{P}<0.05)$. The $t$-test showed that animals treated with ANG II significantly increased saline ingestion when compared with control (Figure 4). Previous injection of animals with $\left[\mathrm{Sar}^{1}, \mathrm{Ala}^{8}\right]$ ANG II and losartan inhibited the saline ingestion induced by ANG II, whereas pretreatment with PD 123319 showed a partial inhibition of the saline intake induced by ANG II.

Injection of only $\left[\mathrm{Sar}^{1}, \mathrm{Ala}^{8}\right]$ ANG II, losartan or PD 123319 into the PVN produced no alterations in water or salt intake.

Effects of [Sar $\left.{ }^{1}, \mathrm{Ala}^{8}\right]$ ANG II, losartan, or PD 123319 injected into the PVN on diuresis and natriuresis induced by ANG II injected into the MSA

The urinary response of rats treated with 
ANG II and of rats pretreated with the antagonists is summarized in Figure 5. Analysis of variance applied to the 2-h cumulative urine excretion indicated a significant difference between groups $(\mathrm{F}(4,44)=14.13$, $\mathrm{P}<0.05)$. Cumulative urine excretion induced by ANG II was inhibited in animals previously treated with $\left[\mathrm{Sar}^{1}, \mathrm{Ala}^{8}\right]$ ANG II and PD 123319, showing no significant differences when compared with saline controls, whereas previous injection of losartan impaired the urine excretion induced by ANG II.

Analysis of variance for the 2-h cumulative sodium excretion data showed a significant difference between groups $(\mathrm{F}(4,44)=$ 24.73, $\mathrm{P}<0.05)$. As can be seen in Figure 6, sodium excretion induced by ANG II increased significantly compared with control rats. Previous administration of $\left[\mathrm{Sar}^{1}, \mathrm{Ala}^{8}\right]$ ANG II blocked the sodium excretion induced by ANG II. Pretreatment with PD 123319 was more effective in decreasing the sodium excretion induced by ANG II when compared with the effects induced by previous administration of losartan.

Injection of only [Sar $\left.{ }^{1}, \mathrm{Ala}^{8}\right]$ ANG II, losartan, or PD 123319 into the PVN produced no alterations in urine or sodium excretion.

\section{Effects of [Sar' ${ }^{1}$, Ala $\left.^{8}\right]$ ANG II, losartan, or PD 123319 injected into the PVN on the increase of arterial pressure induced by ANG II injected into the MSA}

The injection of ANG II $(10 \mathrm{nmol} / 0.5 \mu \mathrm{l})$ into the MSA of conscious normotensive rats $(\mathrm{MAP}=114 \pm 4$ to $123 \pm 6 \mathrm{mmHg}$ in different groups) produced an immediate large increase in MAP $(\triangle \mathrm{MAP}=24 \pm 4$ $\mathrm{mmHg}$ ) compared to the increase in MAP (6 $\pm 2 \mathrm{mmHg}$ ) observed when only $0.15 \mathrm{M}$ $\mathrm{NaCl}$ was injected into the MSA (Figure 7). The largest pressor response after ANG II injection into the MSA was reached within 3 min, with 10-30 min needed for the values to return to baseline.
Previous injection of [Sar $\left.{ }^{1}, \mathrm{Ala}^{8}\right]$ ANG II $(40 \mathrm{nmol})$ and losartan $(40 \mathrm{nmol})$ into the PVN fully abolished, whereas PD 123319 (40 nmol) partially blocked, the pressor response induced by ANG II injection.

\section{Discussion}

The results of the present study confirm reports that the dipsogenic and sodium in-
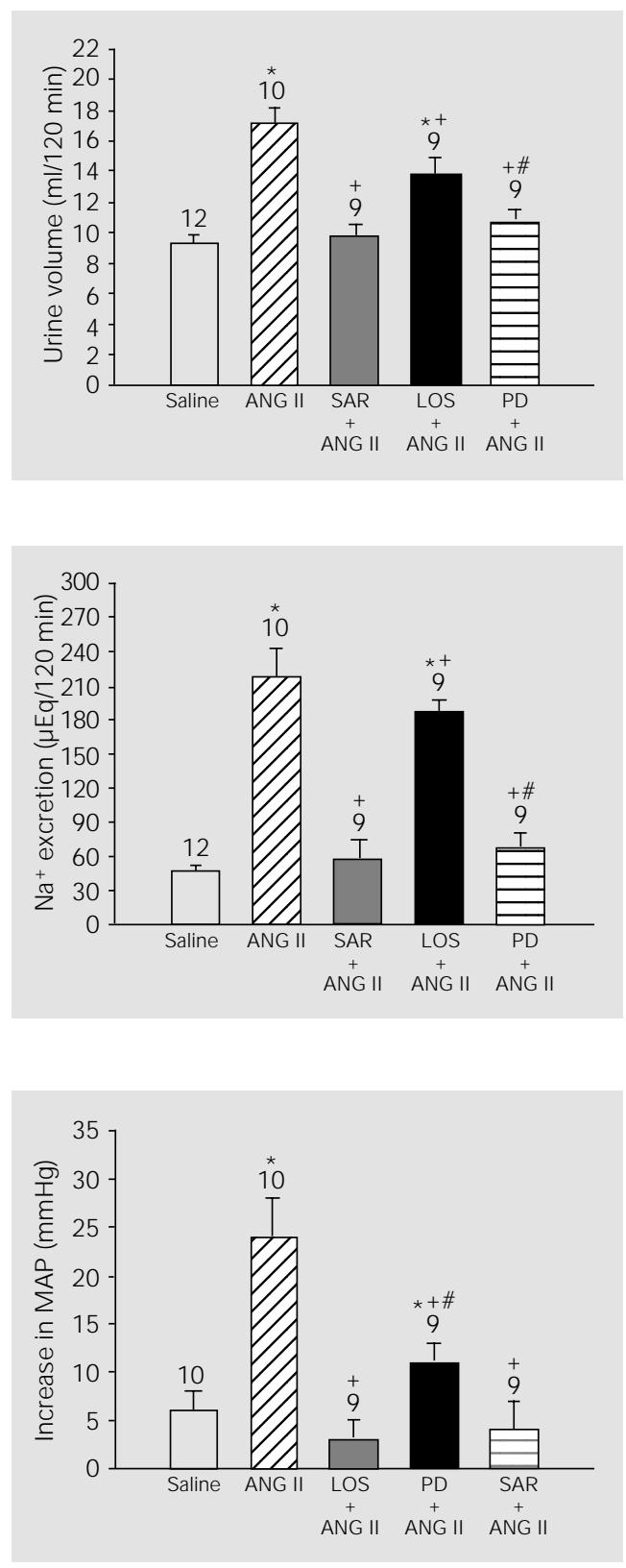

Figure 5. Effect of pretreatment with [Sar ${ }^{1}$, Ala $\left.^{8}\right]$ ANG II (SAR, 40 $\mathrm{nmol}$ ), losartan (LOS, $40 \mathrm{nmol}$ ), and PD 123319 (PD, $40 \mathrm{nmol}$ ) into the paraventricular nucleus on urine excretion induced by injection of ANG II ( $10 \mathrm{nmol})$ into the medial septal area. Data are reported as means \pm SEM. The number of animals is indicated at the top of each column. ${ }^{*} \mathrm{P}<0.05$ compared with saline (control); $+P<0.05$ compared with ANG II; \#P<0.05 compared with losartan (ANOVA).

Figure 6. Effect of pretreatment with [Sar ${ }^{1}$, Ala $\left.^{8}\right]$ ANG II (SAR, 40 $\mathrm{nmol}$ ), losartan (LOS, $40 \mathrm{nmol})$, and PD 123319 (PD, $40 \mathrm{nmol}$ ) into the paraventricular nucleus on sodium excretion induced by injection of ANG II (10 nmol) into the medial septal area. Data are reported as means \pm SEM. The number of animals is indicated at the top of each column. ${ }^{*} \mathrm{P}<0.05$ compared with saline (control); $+P<0.05$ compared with ANG II; \#P $<0.05$ compared with losartan (ANOVA).

Figure 7. Effect of pretreatment with [Sar1 ${ }^{1}$ Ala ${ }^{8}$ ] ANG II (SAR, 40 $\mathrm{nmol}$ ), losartan (LOS, $40 \mathrm{nmol}$ ), and PD 123319 (PD, $40 \mathrm{nmol}$ ) into the paraventricular nucleus on mean arterial blood pressure (MAP) changes induced by injection of ANG II (10 nmol) into the medial septal area. Data are reported as means \pm SEM. The number of animals is indicated at the top of each column. ${ }^{*} \mathrm{P}<0.05$ compared with saline (control); ${ }^{+} \mathrm{P}<0.05$ compared with ANG II; \#P $<0.05$ compared with losartan (ANOVA). 
take action of centrally administered ANG II can be abolished by $\mathrm{AT}_{1}$ receptor antagonists (11). More importantly, the data showed that the $\mathrm{AT}_{2}$ receptor antagonist, $\mathrm{PD} 123319$, also caused a marked reduction of the effects of ANG II on water and sodium intake. After injection of losartan into the PVN the effects of ANG II injection into the MSA on water and sodium ingestion were abolished, indicating that the actions of ANG II were exerted through $\mathrm{AT}_{1}$ receptors. However, $\mathrm{PD}$ 123319 injected into the PVN also inhibited the effects of ANG II, although these effects were not as strong as those observed for losartan.

The present data also demonstrated that the $\mathrm{AT}_{1}$ receptor antagonist caused a reduction of the effects of ANG II on water and sodium excretion. After injection of PD 123319 into the PVN the effects of ANG II injection into the MSA on urine and sodium excretion were totally abolished, indicating that the actions of ANG II were exerted principally through $\mathrm{AT}_{2}$ receptors.

The present data also showed that the hypertensive effect of ANG II administered into the MSA was abolished by losartan and reduced but not abolished by PD 123319 administration into the PVN.

Data about centrally administered $\mathrm{AT}_{2}$ antagonists are controversial. Intracerebroventricular (icv) administration of the $\mathrm{AT}_{2}$ antagonists PD 123319, PD 123177 and CGP 42112 has shown inhibition, no change or increase in water and sodium intake and pressor response to icv ANG II (5). Several studies have shown inhibitory responses to $i c v$ administration of PD 123319 on water and salt intake, vasopressin release and pressor responses to central ANG II in rats (12), while central administration of PD 123177 or CGP 42112 did not interfere with these responses (13). PVN administration of CGP 42112A abolished the diuretic, natriuretic and kaliuretic effects of ANG II injected into the same area (14). There is functional evidence that ANG II exerts excitatory ef- fects on neurons of the PVN and that these effects are antagonized by CGP 42112A (15).

Under the conditions of the present study, if losartan and PD 123319 injected into the $P V N$ were only exerting $\mathrm{AT}_{1}$ and $\mathrm{AT}_{2}$ receptor-selective antagonistic effects, respectively, then the MSA actions of ANG II on water and sodium intake, urinary and sodium excretion and increase in arterial blood pressure are dependent on coactivation of both receptor subtypes. Icv administration of PD 123319 and EXP-3174 (an active metabolite of losartan) has been shown to abolish the cardiovascular response to ANG II, although the profiles of activity of the compounds were different (13). The cardiovascular and behavioral effects of PD 123319 were remarkably similar to those of substance $P$, suggesting that $P D 123319$ may act by releasing endogenous substance $P$. It has been suggested that the inhibitory effects of relatively high doses of PD 123319 injected $i c v$ may be due either to an action on central $\mathrm{AT}_{1}$ receptors or to conversion of $\mathrm{PD} 123319$ to an $\mathrm{AT}_{1}$ antagonist (16). Some data indicate that $\mathrm{AT}_{1}$ and $\mathrm{AT}_{2}$ receptors mediate ANG II-induced water and $\mathrm{NaCl}$ intakes (12) and the cardiovascular responses to ANG II when this peptide is injected either icv (13) or into the hypothalamus (17).

The present data show that losartan injected into the PVN abolished the water and sodium intake and the blood pressure response, and attenuated the diuretic and natriuretic actions of ANG II injected into the MSA. On the other hand, pretreatment with PD 123319 into the same area blocked the urine and sodium excretion, and impaired the water and sodium intake and the pressor response induced by injection of ANG II into the MSA. These data suggest that MSA efferents may release ANG II which acts as a neurotransmitter within the PVN, resulting in postsynaptic effects which in turn influence fluid-electrolyte and blood pressure control. 
Barbosa, Silvia Fóglia, Alexandre A. Vieira, and Silvana A.D. Malavolta. They also thank Ana V. Oliveira for animal care.

\section{References}

1. Phillips MI (1987). Functions of angiotensin in the central nervous system. Annual Review of Physiology, 49: 413-435.

2. J ensen L, Harding JW \& Wright JW (1992). Role of paraventricular nucleus in control of blood pressure and drinking in rats. American J ournal of Physiology, 262: F1068-F1075.

3. Gelsema A \& Calaresu FR (1987). Chemical microstimulation of the septal area lowers arterial pressure in the rat. American J ournal of Physiology, 252: R760R767.

4. Leite DF, Camargo LAA, Saad WA, Renzi A, Fóglia S, De Luca J r LA \& Menani J V (1992). Role of cholinergic and adrenergic pathways of the medial septal area in the control of water intake and renal excretion in rats. Pharmacology, Biochemistry and Behavior, 42: 1-8.

5. Lenkei Z, Palkovits M, Corvol P \& LlorensCortes C (1997). Expression of angiotensin type-1 $\left(\mathrm{AT}_{1}\right)$ and type-2 $\left(\mathrm{AT}_{2}\right)$ receptor mRNAs in the adult rat brain: a functional neuroanatomical review. Frontiers in Neuroendocrinology, 18: 383-439.

6. Allen AM, Moeller I, J enkins TA, Zhuo J , Aldred GP, Chai SY \& Mendelsohn FAD
(1998). Angiotensin receptors in the nervous system. Brain Research Bulletin, 47: 17-28.

7. Ambühl $P$, Felix $D$, Imboden $H$, Khosla MC \& Ferrario CM (1992). Effects of angiotensin analogues and angiotensin receptor antagonists on paraventricular neurons. Regulatory Peptides, 38: 111-120.

8. Wright J W \& Harding J W (1994). Brain angiotensin receptor subtypes in the control of physiological and behavioral responses. Neuroscience and Biobehavioral Reviews, 18: 21-53.

9. Negoro $\mathrm{H}$, Visesswawan $\mathrm{S} \&$ Holland RC (1973). Inhibition and excitation of units in paraventricular nucleus after stimulation of the septum, amygdala, and neurohypophysis. Brain Research, 57: 479-483.

10. Paxinos $G \&$ Watson $C$ (1986). The Rat Brain in Stereotaxic Coordinates Atlas. Academic Press, New York, NY, USA.

11. Beresford MJ \& Fitzsimons JT (1992). Intracerebroventricular angiotensin II-induced thirst and sodium appetite in rat are blocked by the $\mathrm{AT}_{1}$ receptor antagonist, losartan (DuP753), but not by the $A T_{2}$ antagonist, CGP42112B. Experimental Physiology, 77: 761-764.
12. Rowland NE, Rozelle A, Riley PJ \& Fregly J (1992). Effect of nonpeptide angiotensin receptor antagonists on water intake and salt appetite in rats. Brain Research Bulletin, 29: 389-393.

13. Widdop RE, Gardiner SM, Kemp PA \& Bennett T (1993). Differential blockade of central effects of angiotensin II by $\mathrm{AT}_{2-}$ receptor antagonists. American J ournal of Physiology, 265: H226-H231.

14. Camargo LAA \& Saad WA (1999). Renal effects of angiotensin II receptor subtype 1 and 2-selective ligands injected into the paraventricular nucleus of conscious rats. Regulatory Peptides, 84: 91-96.

15. Felix D, Khosla MC, Barnes KL, Imboden H, Montani B \& Ferrario CM (1991). Neurophysiological responses to angiotensin (1-7). Hypertension, 17: 1111-1114.

16. Cooney AS \& Fitzsimons JT (1993). The effect of putative $A T_{2}$ agonist, p-aminophenylalanine-6-angiotensin II, on thirst and sodium appetite. Experimental Physiology, 78: 767-774.

17. Ham NL \& Sim MK (1998). Hypothalamic angiotensin receptor subtypes in normotensive and hypertensive rats. American J ournal of Physiology, 275: H703-H708. 